2. To: (Receiving Organization)
DISTRIBUTION

5. Proj./Prog./Dept./Div.:

VAPOR/AS/SPECIAL/ANALYTICAL/ SUPPORT

8. Originator Remarks:

SST-241-U-104. SAMPLING USING THE VAPOR SAMPLING SYSTEM
3. From: (Originating Organization)

SPECIAL ANALYTICAL SUPPORT $8 C 530$

6. Design Authority/ Design Agent/Cog. Engr.:

RICKY MAHON 3-7437
4. Related EDT No.:

$\mathrm{N} / \mathrm{A}$

7. Purchase Order No.:

$\mathrm{N} / \mathrm{A}$

9. Equip./Component No.:

$\mathrm{N} / \mathrm{A}$

10. System/Bldg./Facility: $622 \mathrm{G}$

11. Receiver Remarks: 11A. Design Baseline Document? [] res $[X]$ No
12. Major Assm. Dwg. No.:

$N / A$

13. Permit/Permit Application No.: N/A

14. Required Response Date:

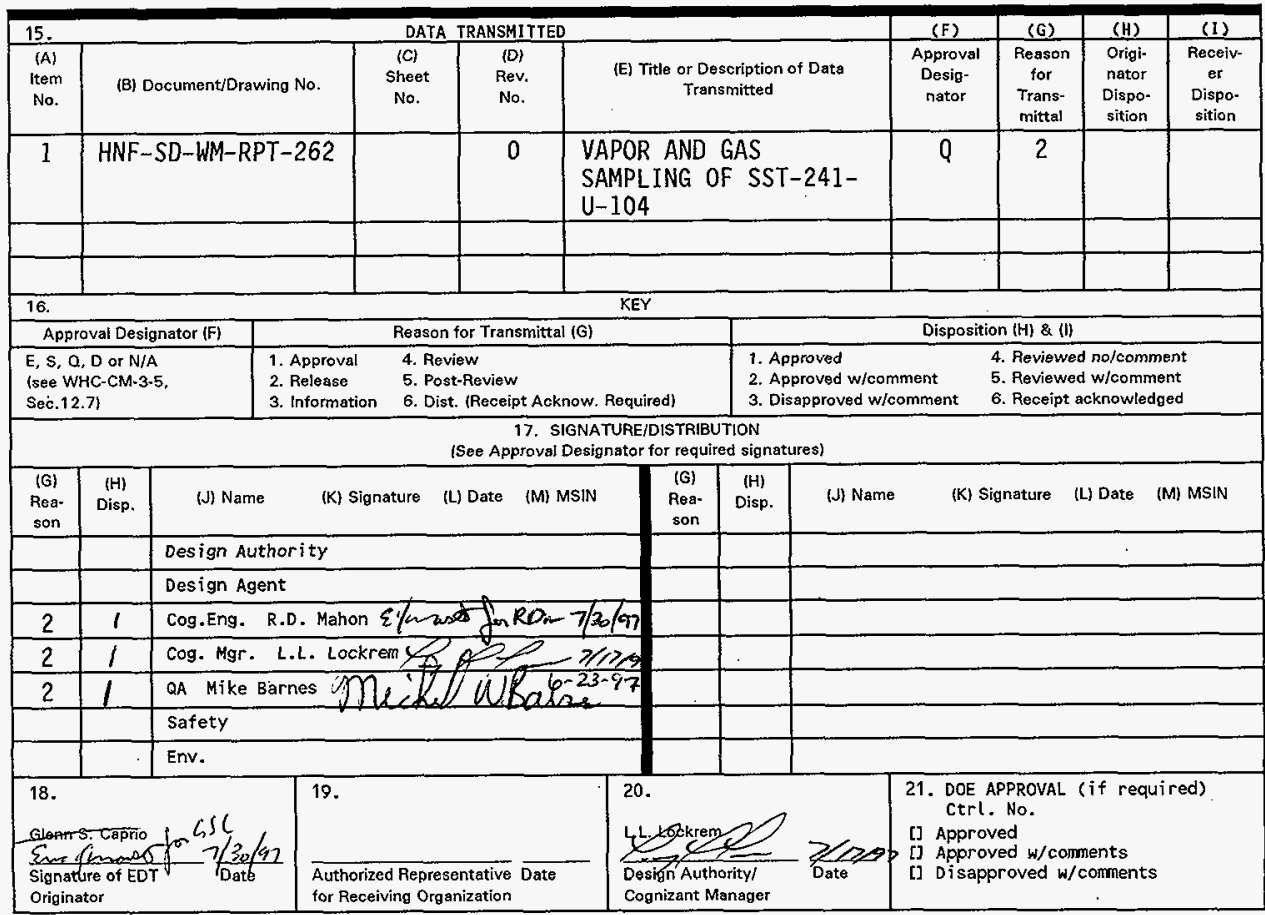




\section{VAPOR AND GAS SAMPLING OF SINGLE-SHELL TANK 241-U-104 USING the in Situ Vapor Sampling System}

\section{G.S. Caprio}

SGN Eurisys Services Company, Richland, WA 99352

U.S. Department of Energy Contract DE-AC06-96RL13200
EDT/ECN: 621402
Org Code: $8 \mathrm{C} 530$
UC: 2070
B\&R Code: EW3120074
Charge Code: E62000
Total Pages: 34

Key Words: 241-U-104, ISVS, SUMMA ${ }^{\text {TM }}$, TST, SORBENT, TANK

Abstract: THIS DOCUMENT PRESENTS SAMPLING DATA RESULTING FROM THE JULY 16, 1996 SAMPLING OF SST 241-U-104

SUMMA is a trademark of Molectrics, Inc.

TRADEMARK DISCLAIMER. Reference herein to any specific commercial product, process, or service by trade name, trademark, manufacturer, or otherwise, does not necessarily constitute or imply its endorsement, recommendation, or favoring by the United States Government or any agency thereof or $i$ ts contractors or subcontractors.

Printed in the United States of America. To obtain copies of this document, contact: Document Control Services, P.O. Box 950, Mailstop H6-08, Richland WA 99352, Phone (509) 372-2420; Fax (509) 376-4989.
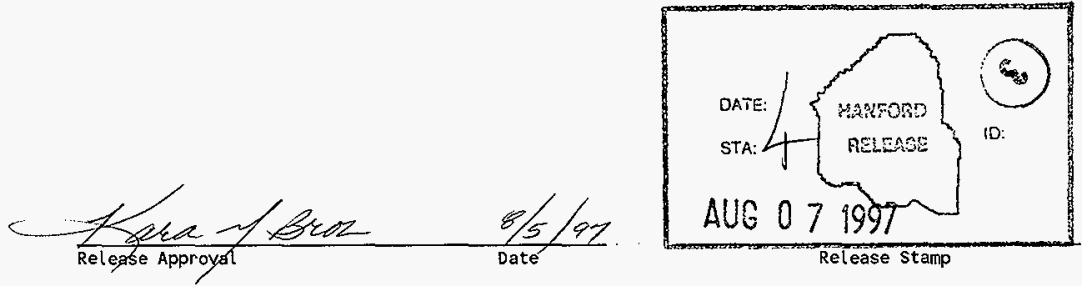

\section{Approved for Public Release}


HNF - SD - WM-RPT-262，Rev . 0

APRROVALS

Document title:

Vapor and Gas Sampling of Single-Shell Tank 241-U-104 Using the In situ vapor Sampling System

Approved by:

G. S. Caprio, Field Scientist

Date

Vapor Sampling Project

Special Analytical Studies

Approved by:

R. D. Mahon, Project Lead

Date

Vapor Sampling Project

Special Analytical Studies

Approved by:

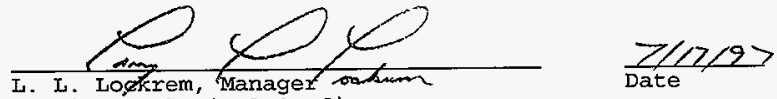
Special Analytical Studies 
CONTENTS

$1.0 \mathrm{SCOPE}$. . . . . . . . . . . . . . . . . . . . . . . . . . 1

2.0 SAMPLING EQUIPMENT DESCRIPTION . . . . . . . . . . . . . . . . . . . . 1 2.1 IN SITU VAPOR SAMPLING SYSTEM . . . . . . . . . . . . . . . . . 1

3.0 SAMPLING EVENT DESCRIPTION . . . . . . . . . . . . . . . . . . . . . . 2 3.1 SPECIFICATIONS . . . . . . . . . . . . . . . . . . . . 2 3.2 OPERATIONS AND SAMPLING PERSONNEL . . . . . . . . . . . . . . . 2 3.3 INDUSTRIAI HYGIENE FIELD RESULTS . . . . . . . . . . . . . . . . 2 3.4 AMRIENT CONDITIONS . . . . . . . . . . . . . . . . . . . . . 3 3.5 SAMPLE COLIECTION . . . . . . . . . . . . . . . . . . . . . . 3 3.6 RADIATION SCREENING . . . . . . . . . . . . . . . . . . 3

4.0 SAMPLE CHAIN OF CUSTODY: RECEIPT, STORAGE, AND SHIPMENT . 5

5.0 QUALITY ASSURANCE AND CONTROLS . . . . . . . . . . . . . . . . . . . 6 5.1 CLEANLINESS OF SYSTEM . . . . . . . . . . . . . . . . . . . . . 6 5.2 INSTRUMENT CALIBRATION . . . . . . . . . . . . . . . . . . . . 6 5.3 BLANK SAMPLES . . . . . . . . . . . . . ........... . . 7

6.0 ANOMALIES . . . . . . . . . . . . . . . . . . . . . . 7

7.0 REFERENCES ........................... . . . . 8

AP PENDICES

SAMPLE LOG SHEETS . . . . . . . . . . . . . . . . . . A-1

AMBIENT CONDITIONS ....................... . . . . . . . .

CHAIN-OF-CUSTODY FORMS ......................... . . C-1 
HNF - SD-WM-RPT-262， Rev. 0

\section{IIST OF TABLES}

1. Radionuclide Analysis Results for Sorbents. . . . . . . . . . . . . . 5

2. Radionuclide Analysis Results for TSTs. . . . . . . . . . . . . . . . 5

3. Calibration Data . . . . . . . . . . . . . . . . . . . 6

4. Totalizer Calibration Data . . . . . . . . . . . . . . . . . . . 7 
HNF-SD-WM-RPT-262, Rev, 0

\section{IIST OF TERMS}

\section{CGI \\ $\mathrm{COC}$ \\ DOT \\ GEA \\ ISVS \\ $\mathrm{NH}_{3}$ \\ $\mathrm{H}_{2} \mathrm{O}$ \\ $\mathrm{OPC}$ \\ OVM \\ PNNL \\ SAS \\ SHA. \\ SMI \\ SST \\ TCP \\ TOC \\ TST \\ VT \\ WHC \\ WSCF}

Combustible Gas Indicator

Chain of Custody

U.S. Department of Transportation

Gamma Energy Analysis

In Situ Vapor Sampling System

Ammonia

Water Vapor

Offsite Property Control

Organic Vapor Meter

Pacific Northwest National Laboratory

Special Analytical Studies

Sample Head Assembly

Sampling and Mobile Laboratories

Single-Shell Tank

Tank Characterization Plan

Total Organic Carbon

Triple Sorbent Trap

Vapor Team, personnel from Sampling and Mobile

Laboratories and Special Analytical Studies

Westinghouse Hanford Company

Waste Sampling and Characterization Facility 
HNF - SD-WM-RPT-262，Rev . 0

This page intentionally left blank. 
HNF - SD - WM-RPT-262, Rev. 0

VAPOR AND GAS SAMPLING OF SINGLE-SHELI TANK 24I-U-104

USING THE IN SITU VAPOR SAMPLING SYSTEM

\subsection{SCOPE}

The Vapor Issue, Resolution Program tasked the Vapor Team (VT) to collect representative headspace samples from Hanford site single-shell tank (SST) 241-U-104. This document presents In Situ vapor Sampling System (ISvS) data resulting from the July 16, 1996 sampling of SST 241-U-104. Analytical results will be presented in separate reports issued by the Pacific Northwest National Laboratory (PNNL) which supplied and analyzed the sample media.

\subsection{SAMPIING EQUIPMENT DESCRIPTION}

\subsection{IN STTU VAPOR SAMPIING SYSTEM}

The VT, consisting of Sampling and Mobile Laboratories (SML) and Special Analytical Studies (SAS) personnel, used the Isvs to collect representative samples of the air, gases, and vapors from the headspace of SST $241-\mathrm{U}-104$ on July 16, 1996. WHC-SD-WM-SDD-068 Rev. 0, System Design Description for the In Situ Vapor Sampling System (Blanchard 1996a) describes, in detail the Isvs performance, its characteristics, and its operation.

In situ sampling is a method designed to collect vapor samples of the homogeneous headspace of waste tanks. Sample media, consisting of sorbent traps and radiological filters, are lowered into the tank headspace. Tank gases are drawn through the media by means of the Isvs manifold, which measure the volume of gas drawn through the system. The sample media are collected together in a sample head assembly (SHA). The SHA provides for twelve sorbent or triple sorbent trap (TST) samples (single sample each) to be sampled in sets of four, one SUMMA sampling line, and one line for radiological

filtration.

The SHA is protected from external contamination and breakage by a transparent plastic tube. The plastic tube is cut, formed, and connected to the SHA. The plastic tube also prevents any part of the SHA from accidentally falling into the tank.

A set of $1 / 4$ or $5 / 16$ inch diameter flexible tubes, approximately 50 feet long, are held together with spiral wrap to form a "tube bundle", which connects the ISVS to the SHA. The tube bundle and SHA are assembled prior to sampling and are referred to as the "sample assembly".

Sorbent traps are pencil-size stainless steel or glass tubes that contain vapor-adsorbing media. The sorbent traps may be used singly or may be prepared with several individual traps joined in series (a sorbent train). A known amount of sample vapor is passed through the tube, which traps (by adsorption) virtually all the target analytes. The concentration of analytes in the vapor sampled is calculated from the quantity of analyte found in the sorbent media and the volume of vapor passed through the sorbent trap. In addition to the sorbent traps, SUMMA canisters are also used to collect samples.

SUMMA" canisters are stainless steel vessels with internal surfaces that have been prepared by the SUMMA" process, which passivates active sites on the canister walls to minimize adsorption of gases and vapors. An analytical laboratory must clean and evacuate SUMMA canisters before each use. The 
HNF - SD-WM-RPT-262, Rev. 0

evacuated canister is filled with sample vapor through a valve, which is then closed to seal the sample inside. SUMMA" canisters allow collection and transfer of whole-air samples from location to an analytical laboratory where the sample is analyzed. The standard capacity of each SUMMA" canister is 6 liters.

The ISVS consists of five sample stations, (four for sorbent trap sampling and one for SUMMA sampling) terminating in $1 / 4$ inch outside diameter stainless steel tubing. Each sorbent sample station is independently operable at the selected flow rate, from 50 to 500 standard cubic centimeters per minute (sccm).

The system is a portable sampling system. It is designed to allow setup and preparation to be performed outside of the tank farm, with a minimum number of steps to be performed inside the farm. It operates on $110 \mathrm{~V}$ AC power. The ISVS was designed to meet the requirements of National Fire Protection Association 70 - 1993 (the National Electrical Code) for general industrial use. Before the ISVS can be used in any tank, procedures require a flammability check of the waste tank which shows that concentrations of flammable materials are well below lower flammability limits.

Tank gases passing through the ISVS will either pass through a sorbent trap and then a backup line dryer, or through the on-board activated charcoal/drierite cartridge. A check valve is installed in the system to prevent any possibility of siphoning materials into the waste tanks.

\subsection{SAMPLING EVENT DESCRIPTION}

\subsection{SFECIFICATIONS}

The Vapor Issue Resolution Program specifies sampling requirements in WHC-SD-WM-TP-335 Rev. 2A, Vapor Sampling and Analysis Plan (Buckley 1996b). The Sampling and Analysis Plan also specifies the types and number of samples to be collected, flow rates, and durations. These key sampling parameters are summarized on the sample log sheets in Appendix A. In addition to the sample log sheets, checksheets for each individual sample help ensure correct sampling procedures. The VT retains these documents in the project file. The project specific number for this sampling event is $\$ 6-072$.

\subsection{OPERATIONS AND SAMPLING PERSONNEL}

Steve Carter was the Tank Farm Operations person-in-charge. The VT members included:

G. S. Caprio, Field Scientist

R. D. Mahon, Lead Scientist

C. S. McClellan, Sampling Technician.

The ISVS was set up at SST 241-U-104 on July 16, 1996 and was allowed to warm up for approximately 15 minutes. Sampling began at approximately 1127 on July 16, 1996, and was completed by 1350 the same day.

\subsection{INDUSTRIAL HYGIENE FIELD RESULTS}

priox to inserting the tube bundle into SST 241-U-104, an industrial hygiene technician field tested tank vapors. The technician purged the instrument with tank gas for 5 minutes and then field measured vapor stream contents using a combustible gas indicator (CGI) and an organic vapor meter (OVM). The 
HNF - SD - WM-RPT-262, Rev . 0

technician measured the tank vapors at the breather filter, three feet down the riser, and twenty four feet down the riser. The measurements reported at the breather filter: LEL $0 \%, \mathrm{NH}_{3} 0 \mathrm{ppm}, \mathrm{O}_{2} 21.0 \%$, and TOC $0 \mathrm{ppm}$. The measurements approximately three feet down were: LEL $0 \%$, $\mathrm{NH}_{3} \mathrm{O} \mathrm{ppm}, \mathrm{O}_{2} 21.0 \%$, and TOC $0 \mathrm{ppm}$. The measurements approximately twenty four feet down were: LEI $0 \%, \mathrm{NH}_{3} 0 \mathrm{ppm}, \mathrm{O}_{2} 21 \%$, and TOC 0 ppm.

\subsection{AMBIENT CONDITIONS}

The weather the day of the sampling event, July 9, 1996, was sunny and clear with winds approxiametely $5 \mathrm{mph}$ from the northwest. Graphs of ambient temperatures and pressures taken at the Hanford Meteorological Station, which is about 2 miles north east of U-Farm, are provided in Appendix B.

\subsection{SAMPLE COLLECTION}

one analytical laboratory provided sample media. PNNL provided SUMMA" canisters, sorbent traps for organic vapors, ammonia $\left(\mathrm{NH}_{3}\right)$, $\mathrm{NO}_{\mathrm{X}}$, and water vapor $\left(\mathrm{H}_{2} \mathrm{O}\right)$.

The VT began inserting the sample media into the SHA at 1100 on July 15, 1996 , and finished at approximately 1200. The SHA was connected to tube bundle $14 \mathrm{E}$. The top collar as described in ECN \#632433 was used for this sampling event. The sample assembly was transported to 241-U-104 on July 16, 1996, and connected to Isvs \#1 for the sampling event.

prior to sample collection, a leak check of the ISVS sampling manifold and transfer tubing was performed. Pressure gauge readings were recorded at the beginning of the leak check. The gauge readings were used for the leak check calculations but for report purposes will be converted to absolute pressure. The system was evacuated to approximately 135.46 mbar (4 inHg) and leakage of ambient air into the system was observed by monitoring system pressure for 5 minutes. Leakage resulted in an increase of 0 mbar $(0 \mathrm{inHg})$ in system pressure during the 5 minute test.

The tank flange was opened and the tube bundle was lowered 7.3 meters (24 feet). Tank vapor was drawn through each TST, sorbent, and SUMMA line for a specified period of time. Appendix A indicates the exact times and volumes of tank gas that was drawn through each sample.

After the final sample was collected the sample assembly was removed from the tank. Following the HPT survey the SHA was transported to WSCF and stored in a cusody secure RMA, then disassembled in a hood the following day. plugs were placed in the c-flex inlets and c-flex clamps on the $1 / 4$ inch Tygon tubing coming out of the Top Collar to isolate the samples from ambient conditions. After disassembly, the in-line filters were txansported to $222-\mathrm{s}$ for analysis.

The ISVS was left in U Farm until it could be surveyed by an HPT and transported to B Farm for the next sampling event.

\subsection{RADIATION SCREENING}

Radiological screening results are used to determine (1) if the samples must be shipped as radioactive or nonradioactive in accordance with U.S. Department of Transportation (DOT) regulations and (2) if the samples meet the laboratory acceptance criteria.

The DOT limits for shipping a nonxadioactive sample are 2000 combined pCi/g of beta-gamma activity and alpha activity. Samples exceeding these DOT limits 
may be shipped as radioactive material if the samples do not exceed the following laboratory acceptance criteria:

PNNL: $\quad$ Beta-gamma activity $<15 \mathrm{pCi} / \mathrm{g}$ of sample media. Alpha activity $<5 \mathrm{pCi} / \mathrm{g}$ of sample media.

The sample media was not filtered for radiological particulates. The idea of unfiltered samples was to provide better analytical data for the laboratories. The samples were released for shipment based on a the analytical results of the series of two filters and tritium trap collected through one of the $1 / 4$ inch flexible lines. Based on the radiological results for the filters and tritium trap it is believed that the same concentration of radiological contaminates passed through the other 13 lines.

On July 17, 1996, the particulate filters and silica gel were delivered to $222-S$ Laboratory. $222-S$ Laboratory performed analysis on the filters on July 18, 1996, and transmitted the results to the VT. The VT scientists reviewed the data and determined that the results did not allow the VT to ship the sample media to PNNL. On July 23, 1996, another analysis was requested to observe any decay. The analytical results of the second analysis showed very little decay and were still too high to ship. A third analysis was requested on July 28, 1996. The third analysis showed little change from the second. On July 31, 1996, the Vapor Sampling Program office was notified of the elevated analytical results and the VT requested guidance.

On August 2, 1996, PNNL requested that the NH3 and H20 tubes from sample S6072-A07.34R be sacrificed for radiological analysis by WSCF. They requested that the sorbent tube be crushed and the remnants be analyzed for total alpha, total beta, and GEA. PNNL also requested that they review the analytical results from the analysis and determine if they are acceptable to deliver as non-radioactive.

On August 7, 1996, the Vapor Program office gave authorization to have WSCF analyze the sacrificial sorbent tube. Details were worked out between August 7,1996 and October 3, 1996, on how the analysis would be performed and if the laboratory had the capability to perform the analysis.

On October 8,1996 , the sorbent tube S6072-A07.34R was submitted to WSCF, crushed, and analyzed for total alpha, total beta, and GEA. The analytical results of the analysis were reported to the VI on October 10, 1996. The results were transmitted to PNNL for their scientific review on october 18 , 1996. On October 29, 1996, PNNL requested that the sorbent tubes be returned to them as non-radioactive samples. The samples were returned to PNNL on October 29, 1996, and delivered to J.A. Edwards. The analytical data used to release the sorbent tubes is provided in Table 1 . 
HNF - SD-WM-RPT-262, Rev. 0

Table 1. Radionuclide Analysis Results for Sorbents.

\begin{tabular}{|c|c|c|c|}
\hline Filter & $\begin{array}{c}\text { Sample } \\
\text { Identifier }\end{array}$ & $\begin{array}{c}\text { Activity Results } \\
\text { (pCi/sample) }\end{array}$ & $\begin{array}{c}\text { Activity } \\
\text { (pci/L of tank } \\
\text { gas) }\end{array}$ \\
\hline$N / A$ & S6071-A07.34R & $\begin{array}{c}\text { Total Alpha =<detectable } \\
\text { Total Beta =<detectable } \\
\text { GEA = <detectable }\end{array}$ & $\begin{array}{l}=\text { <detectable } \\
=<\text { detectable } \\
=\text { <detectable }\end{array}$ \\
\hline $\mathrm{N} / \mathrm{A}$ & $\begin{array}{c}S 6071-\mathrm{AO} 7.34 \mathrm{R} \\
34 \mathrm{RE}\end{array}$ & Total Activity $=<3.78$ & $=<$ detectable \\
\hline
\end{tabular}

NOTES :

The samples are nonradioactive. These results were evaluated against laboratory acceptance criteria and DOT limits.

${ }^{2} \mathrm{All}$ less than (<) values represent the minimum detection limits at Laboratory $222-S$.

'Numbers based on 2 liters for the total volume of tank vapor through the sorbent tube.

The TST samples did not require further radiological analysis. Based on the analytical results provided in Table 2 the TSTs were shipped to PNNL and delivered to Jeff Edwards on October 8, 1996.

Table 2. Radionuclide Analysis Results for TSTs.

\begin{tabular}{|c|c|c|c|}
\hline Filter & $\begin{array}{c}\text { Sample } \\
\text { Identifier }\end{array}$ & $\begin{array}{c}\text { Activity Results } \\
\text { (pCi/sample) }\end{array}$ & $\begin{array}{l}\text { Activity } \\
\text { (pCi/I of tank } \\
\text { gas) }\end{array}$ \\
\hline Upstream Filter & S6071-A21. OU1 & $\begin{array}{l}\text { Total Alpha }=<0.187 \\
\text { Total Beta }=40.7 \\
\text { GEA }=46.2\left({ }^{137} \mathrm{Cs}\right)\end{array}$ & $\begin{array}{c}=\text { <detectable } \\
=40.7 \\
=46.2\end{array}$ \\
\hline Downstream Filter & S6071-A22.OD1 & $\begin{array}{l}\text { Total Alpha }=0.27 \\
\text { Total Beta }=34.7 \\
\text { GEA }=45.4 \quad\left({ }^{137} \mathrm{Cs}\right)\end{array}$ & $\begin{array}{l}=0.27 \\
=34.7 \\
=45.40\end{array}$ \\
\hline Tritium Trap & S6071-A03.OT1 & Total Activity $=7.42$ & $=7.42$ \\
\hline
\end{tabular}

NOTES :

The samples are nonradioactive. These results were evaluated against laboratory acceptance criteria and DOT limits.

${ }^{2} \mathrm{Al} 1$ less than (<) values represent the minimum detection limits at Laboratory $222-\mathrm{S}$.

'Numbers based on 1 liter for the total volume of tank vapor through the filters.

\subsection{SAMPLE CHAIN OF CUSTODY: RECEIPT, STORAGE, AND SHIPMENT}

All sorbent trains, TSTs, and SUMMA canisters received from PNNL are kept in a custody locked storage area maintained by SML. Sorbent trains and TSTs were maintained at $4 \pm 2{ }^{\circ} \mathrm{C}$ in a refrigeration unit. SUMMA ${ }^{m}$ canisters were stored in the same locked storage area, but were not refrigerated. The sample media was picked up from PNNL by SAS and transported in a government vehicle to a custody locked storage area. Appendix C lists the sample identifiers, sample types, and COC form numbers for the sampling event.

From the time that samples are received by SAS until they are shipped back to the analytical laboratory, all COCs are maintained by SAS in accordance with WHC-IP-1127-1.3, Chain-of-Custody/Special Analysis Request for RCRA and CERCLA Protocol Samples (WHC 1995a). 


\subsection{QUALITY ASSURANCE AND CONTROLS}

\subsection{CLEANLINESS OF SYSTEM}

Immediately prior to sampling of SST 241-U-104, the ISVS manifold was purged with ambient air for 5 minutes at $1 \mathrm{~J} / \mathrm{min}$. After this purge an ambient aix SUMMA sample was drawn through the ISVS manifold and the $1 / 4$ inch SUMMA sampling line. A second ambient air SUMMA" sample was collected 10 meters upwind from the tank breather filter. The ambient air samples were then collected to confirm by laboratory analysis that the Isvs sampling manifold was free of trace organic contaminants (or to determine which contaminants were present and at what concentration). For further details, refer to WHC-IP-1127-4.8 (WHC 1995b) and the project-specific file located with the VT.

\subsection{INSTRUMENT CALIBRATION}

The Isvs uses mass flow meters to measure the flow rate and totalizers to measure the total volume of sample vapor drawn through the sample media. Errors associated with the mass flow meters and totalizers were determined by the Westinghouse Hanford Company (WHC) Standards Laboratory before the SST 241-U-104 sampling event. Duration of flow are specified by the analytical laboratories that supply and analyze the sorbent traps.

Table 3. Calibration Data.

\begin{tabular}{|c|c|c|c|}
\hline Element & Calibration Date & Expiration Date & $\begin{array}{l}\text { WHC Standards } \\
\text { Laboratory Code }\end{array}$ \\
\hline $\begin{array}{c}\text { Rotameter AALBORG } \\
102-05\end{array}$ & $8 / 8 / 95$ & $8 / 8 / 96$ & $518-28-13-001$ \\
\hline $\begin{array}{c}\text { Digital } \\
\text { Thermometer HH22 }\end{array}$ & $1 / 11 / 96$ & $1 / 11 / 97$ & $518-79-06-003$ \\
\hline $\begin{array}{l}\text { Vacuum Gauge } \\
\text { ASHCROFT }\end{array}$ & $8 / 7 / 95$ & $8 / 7 / 96$ & $518-31-05-003$ \\
\hline $\begin{array}{l}\text { Headspace } \\
\text { Thermocouple }\end{array}$ & $5 / 31 / 96$ & $5 / 31 / 97$ & $518-78-02-010$ \\
\hline $\begin{array}{c}\text { Mass Flowmeters } \\
\text { Sierra } 822-13 \text {-OV1 } \\
\text { FM-1/FT-1 }\end{array}$ & $8 / 8 / 95$ & $8 / 8 / 96$ & $518-28-03-015$ \\
\hline $\begin{array}{c}\text { Mass Flowmeters } \\
\text { Sierra } 822-13-\text { OV1 } \\
\text { FM-2/FT-2 }\end{array}$ & $8 / 8 / 95$ & $8 / 8 / 96$ & $518-28-03-016$ \\
\hline $\begin{array}{c}\text { Mass Flowmeters } \\
\text { Sierra } 822-13-\text { OVI } \\
\text { FM-3/FT-3 }\end{array}$ & $8 / 8 / 95$ & $8 / 8 / 96$ & $518-28-03-017$ \\
\hline $\begin{array}{c}\text { Mass Flowmeters } \\
\text { Sierxa } 822-13-\text { OV1 } \\
\text { FM-4/FT-4 }\end{array}$ & $8 / 8 / 95$ & $8 / 8 / 96$ & $518-28-03-018$ \\
\hline
\end{tabular}

Instruments located in the ISVS are calibrated on an annual basis at the wHC Standards Laboratory. Isvs instrumentation calibration data, maintained in files by the VT, are summarized in Table 3 . According to the calibration 
schedule shown in Table 2, all instrumentation was within its calibration period during the SST 24I-U-104 sampling event.

"Due to calibration discrepancies, the mass flow measurements for this sampling event may have an error of $6 \%$ to $14 \%$. A detailed description of this discrepancy can be found in internal memo 75820-96-028".

The totalizers were calibrated in conjunction with the mass flow meters and the calibration data is summarized in Table 4.

Table 4. Totalizer Calibration Data.

\begin{tabular}{|c|c|c|c|c|c|c|c|}
\hline Number & $\begin{array}{c}\text { Calibration } \\
\text { Date }\end{array}$ & $\begin{array}{c}\text { Expiration } \\
\text { Date }\end{array}$ & $\begin{array}{c}\text { Flow Rate } \\
(\text { stdcm } / \mathrm{min})\end{array}$ & $\begin{array}{c}\text { Time } \\
\text { (min) }\end{array}$ & $\begin{array}{c}\text { Calc. } \\
\text { Total }\end{array}$ & UUT & Deviation \\
\hline $\begin{array}{c}3494-1 \\
\text { FT-1 }\end{array}$ & $8 / 8 / 95$ & $8 / 8 / 96$ & 247.1 & 5.833 & 1441.2 & 1500 & $3.9 \%$ \\
\hline $\begin{array}{c}3494-2 \\
\text { FT-2 }\end{array}$ & $8 / 8 / 95$ & $8 / 8 / 96$ & 253.8 & 7.065 & 1793.1 & 1800 & $0.4 \%$ \\
\hline $\begin{array}{c}3494-3 \\
\text { FT-3 }\end{array}$ & $8 / 8 / 95$ & $8 / 8 / 96$ & 262.7 & 5.081 & 1334.7 & 1300 & $2.6 \%$ \\
\hline $\begin{array}{c}3494-4 \\
\text { FT-4 }\end{array}$ & $8 / 8 / 95$ & $8 / 8 / 96$ & 25.2 & 5.186 & 1302.8 & 1300 & $0.2 \frac{\circ}{8}$ \\
\hline \hline
\end{tabular}

\subsection{BLANK SAMPLES}

Trip blanks are samples that accompany the sample media from the point of generation through sample analysis. They are transported to the field with the sample collection media but remain unopened during the sampling event. Analysis of trip blanks is used to assess cross-contamination of sample media during field transport and storage.

Field blanks are sampling devices similar to trip blanks. They are prepared and handled in the same manner as the sampling media, but no tank vapors are drawn through them.

Spiked blanks are prepared as regular sampling media but also contain a known amount of special analyte. Tank vapors are drawn through these blanks and they are handled and analyzed just like any other sample. Analysis of the spiked blanks is used to evaluate potential sample loss during shipment or storage.

Ambient blanks are samples of ambient air collected at the sampling location. Analysis of ambient blanks is used to assess contamination that may be present in the atmosphere or in the transfer tubing or sampling manifold of the ISVS immediately prior to sampling operations.

\subsection{ANOMALIES}

The VT used the Sampling and Analysis Plan and WHC-IP-1127-4.8, Vapor Sampling of Waste Tanks Using In Situ Vapor Sampling System (ISVS), (1995b) to guide the sample collection. There were no reportable anomalies noted during the sampling of 241-U-104. 
HNF - SD-WM-RPT-262, Rev. 0

\section{0 REEERENCES}

49 CFR 100-177, 1992, "Transportation," Code of Federal Regulations, as amended.

Blanchard, R. J., 1996a, System Design Description for the In Situ Vapor Sampling System, WHC-SD-WM-SDD-068 Rev. 0, Westinghouse Hanford Company, Richland, Washington.

Washington.

Buckley, L. I., 1996b, Vapor Sampling and Analysis Plan, WHC-SD-WM-TP-335 Rev. 2A, Westinghouse Hanford Company, Richland, Washington.

Trible, T. C., Viswanath, $\dot{R}$. S., 1996C, Recommendation concerning the ISVS/VSS comparison study data with respect to calibration errors in Mass flow monitors and controllexs, (internal memo 75820-96-028 to L.D. Pennington, August 28), Westinghouse Hanford Company, Richland, Washington.

WHC, 1995a, Chain-of-Custody/Special Analysis Request for RCRA and CERCLA Protocol Samples, Procedure WHC-IP-1127-1.3, Rev. 1, Westinghouse Hanford Company, Richland, Washington.

WHC, 1995b, Vapor Sampling of Waste Tanks Using In Situ Vapor Sampling System (ISVS), Procedure WHC-IP-1127-4.8, Westinghouse Hanford Company, Richland, Washington. 
HNF - SD - WM-RPT-262, Rev . 0

This page intentionally left blank. 
HNF-SD-WM-RPT-262, Rev , 0

APFENDIX A

SAMPLE LOG SHEETS

A-1 
HNF - SD - WM-RPT-262，Rev . 0

This page intentionally left blank.

A -2 
ISVS Sampling of U-104

Set up ISVS (Secton 8.1)

Ensure particulate filtērs are installed

LEAK CHECKIAPPENDIX f) Leak Rate:

Tank Temperature

Ambient Temp.

$32.0 \mathrm{C}$

PNNL Sample Cart

WHC Sample ID

Sample ID Line

Port
Prob

0 inch $\mathrm{Hg}$ in $5 \mathrm{~min}$

Date: $7 / 16 / 96$

ISVS Personnel: Glenn Caprio, Rick Mahon, McClellan

Trailer Personnel: None

$\begin{array}{cccccccccc} & \text { Desired } & \text { Desired } & \text { Desired } & \text { Actual } & \text { Actual } & \text { Actual } & \text { Actual } & \text { Actual } \\ \text { Description } & \text { Flow } & \text { Duration } & \text { Total } & \text { Flow } & \text { Start } & \text { End } & \text { Total } & \text { Total } \\ & \text { Rate } & \text { (min.) } & \text { Flow } & \text { Rate } & \text { Time } & \text { Time } & \text { Time } & \text { Flow } \\ & \text { Sccm } & & \text { scc } & \text { sccm } & & & \text { (tmin.) } & \text { Scc }\end{array}$

Purge SUMMA line of sample line with ambient air

56072 A01.013 013 NA NA

Upwind SUMMA \#1

1000

Ambient \#2

\begin{tabular}{llll}
1000 & 1137 & 1142 & 5 \\
\hline 1135 & 1136 & 1 \\
\hline 1143 & 1144 & 1
\end{tabular}

Uncap and insert sample bundle into tank

1145

1148

Connect bundle lines: $\quad 1$

\begin{tabular}{llllllllll}
\hline S6072 A21. OU1 & OU1 & 1 & 1 & UPSTREAM FILTER & 200 & 5 & 1000 & 213 & NA \\
\hline A22 OD1 & OD1 & DOWNSTRM FILTER \\
A03 OT1 & OT1 & TRITIUM & 1155 & NA \\
\hline
\end{tabular}

Connect bundle lines:

$$
\begin{array}{cc}
\text { S } & \text { SUMMA } \\
\hline 2 & 1 \\
\hline 3 & 2 \\
\hline 4 & 3 \\
\hline 5 & 4
\end{array}
$$

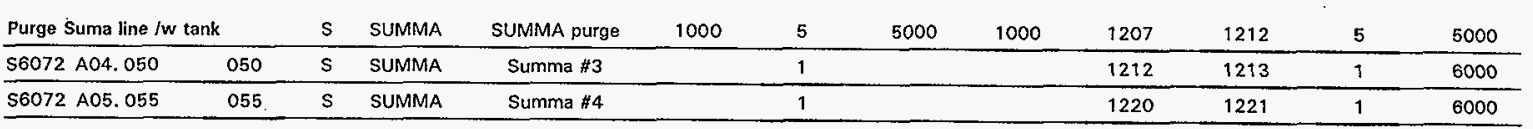


ISVS Sampling of U-104

\begin{tabular}{|c|c|c|c|c|c|c|c|c|c|c|c|c|}
\hline WHC Sample ID & $\begin{array}{l}\text { - PNNL } \\
\text { Sample ID }\end{array}$ & $\begin{array}{l}\text { Probe } \\
\text { Sample } \\
\text { Line }\end{array}$ & $\begin{array}{l}\text { Cart } \\
\text { Port }\end{array}$ & Description & $\begin{array}{l}\text { Desired } \\
\text { Flow } \\
\text { Rate } \\
\text { sccm }\end{array}$ & $\begin{array}{c}\text { Desired } \\
\text { Duration } \\
\text { (min.) }\end{array}$ & $\begin{array}{c}\text { Desired } \\
\text { Total } \\
\text { Flow } \\
\text { scc }\end{array}$ & $\begin{array}{l}\text { Actual } \\
\text { Flow } \\
\text { Rate } \\
\text { sccm }\end{array}$ & $\begin{array}{l}\text { Actual } \\
\text { Start } \\
\text { Time }\end{array}$ & $\begin{array}{c}\text { Actual } \\
\text { End } \\
\text { Time }\end{array}$ & $\begin{array}{l}\text { Actual } \\
\text { Total } \\
\text { Time } \\
\text { (min.) }\end{array}$ & $\begin{array}{l}\text { Actual } \\
\text { Total } \\
\text { Flow } \\
\text { scc }\end{array}$ \\
\hline S6072 A06. 099 & 099 & $\mathrm{~s}$ & SUMMA & Summa $\# 5$ & & 1 & & & 1227 & 1228 & 1 & 6000 \\
\hline S6072 A07. 34R & $34 \mathrm{R}$ & 2 & 1 & $\mathrm{NH} 3 / \mathrm{NO} / \mathrm{H} 2 \mathrm{O}$ & 200 & 10 & 2000 & 213 & 1234 & NA & NA & 2000 \\
\hline \$6072 A08. 35R & $35 \mathrm{R}$ & 3 & 2 & $\mathrm{NH} 3 / \mathrm{NO} / \mathrm{H} 2 \mathrm{O}$ & 200 & 10 & 2000 & 208 & 1234 & NA & NA & 2002 \\
\hline S6072 A09. 36R & $36 \mathrm{R}$ & 4 & 3 & $\mathrm{NH} 3 / \mathrm{NO} / \mathrm{H} 2 \mathrm{O}$ & 200 & 10 & 2000 & 206 & 1235 & NA & NA & 2000 \\
\hline S6072 A10. 37R & $37 R$ & 5 & 4 & $\mathrm{NH} 3 / \mathrm{NO} / \mathrm{H} 2 \mathrm{O}$ & 200 & 10 & 2000 & 200 & 1235 & NA & NA & 2000 \\
\hline
\end{tabular}

Connect bundle lines:

\begin{tabular}{ll}
6 & 1 \\
\hline 7 & 2 \\
\hline 8 & 3 \\
\hline 9 & 4 \\
\hline
\end{tabular}

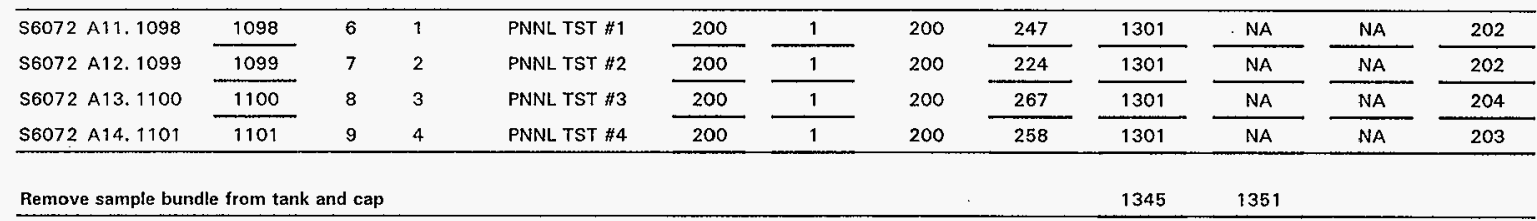

\section{Dismantle sample bundle}

\begin{tabular}{|c|c|c|c|c|}
\hline S6072 A21. OU1 & S96WV0095C & 1 & 1 & Bundle line 1 Upstream filter \\
\hline S6072 A22, OD1 & S96WV0096C & 1 & 1 & Bundle line 1 Downstream filter \\
\hline S6072 A03. OT1 & s96WV0097 & 1 & 1 & Bundle line 1 tritium trap \\
\hline S6072 A.15. 38R & $38 R$ & 10 & NA & Bundle store NH3/NOx/H2O FIELD BLANK $\# 1$ \\
\hline S6072 A16. 39R & 39R & 11 & NA & Bundle store $\mathrm{NH} 3 / \mathrm{NO} / \mathrm{H} 2 \mathrm{O}$ FIELD BLANK $\# 2$ \\
\hline$\$ 6072$ A17. 1102 & PNNL \#1102 & 12 & NA & Bundle store PNNL TST FIELD BLANK \#1 \\
\hline$\$ 6072$ A18. 1103 & PNNL \#1103 & 13 & NA & Bundle store PNNL TST FIELD BLANK $\# 2$ \\
\hline 56072 A19. 1104 & PNNL \#1104 & NA & NA & Bundle store PNNL TST TRIP BLANK \#1 \\
\hline$\$ 6072$ A20. 1105 & PNNL \#1105 & NA & NA & Bundle store PNNL. TST TRIP BLANK \#2 \\
\hline
\end{tabular}


ISVS Sampling of U-104

\begin{tabular}{|c|c|c|c|c|c|c|c|c|c|c|c|c|}
\hline & & Probe & & & Desired & Desired & Desired & Actual & Actual & Actual & Actual & Actual \\
\hline$H C S C$ & PNNL & Sample & Cart & Description & Flow & Duration & Total & Flow & Start & End & Total & Total \\
\hline HC Sample :L & & & & & sccm & & sec & $\begin{array}{l}\text { Hate } \\
\text { sccm }\end{array}$ & & & Imin. & $\begin{array}{l}\text { How } \\
\text { scc }\end{array}$ \\
\hline
\end{tabular}

Remove filters from cart manifold ports $1,2,3,4$, and SUMMA to release cart.

BUNDLE TOTAL TANK GAS USED DURING SAMPLING RUNS (Liters)

Note: SCCM for the ISVS is reported at 760 torr, $21 \mathrm{C}$ 
Note: HVALUE! : < <etectabse

\$6072-A21.OU1 / \$96WVO095C PARALLEL UPSTREAM FILTER TOTAL VOLUME

ALPHA

BETA

GEA - $\quad \cos$

Cs- 134

Cs- 137

$E \mathrm{U}-152$
$\mathrm{Eu}-154$

EU-15S

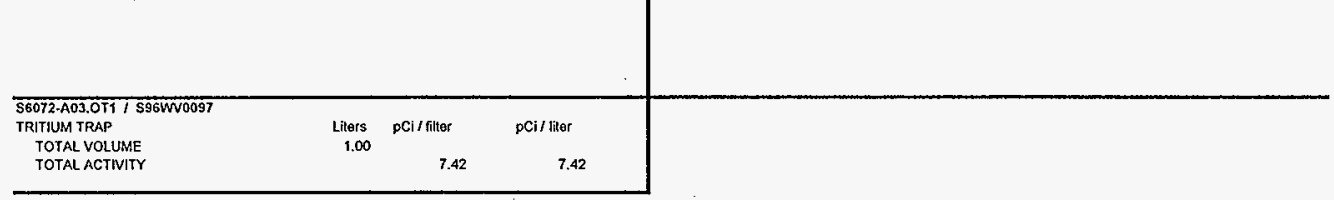

SAMPLE EXPOSURE ANALYSIS, USING TOTAL OF BOTH UPSTREAM AND DOWNSTREAM FILTER ANALYSIS AS POSSIBLE EXPOSURE LEVEL

$=$ BETA and ALPHA Less than DOT shipping timils

Tota! Alpha (pCi $/$ ititer) $=\quad 0.27$

$\begin{array}{ll}\text { Total Beta (pCiliter) } & \text { I } \\ \text { Total GEA Cs-137 (pCi / liter) }= & 75.40 \\ & \end{array}$

The

\begin{tabular}{|c|c|c|c|}
\hline \multicolumn{4}{|c|}{ SOREENT SAMPLING Used $5 \mathrm{~g}$ for sorbent mass } \\
\hline \multicolumn{4}{|l|}{$\begin{array}{l}\text { TOTAL VOLUME PER SAMPLE } \\
\text { Tritium POS SAMPLE }\end{array}$} \\
\hline NH3 (5 gram) & 2.97 pCi per gram & TST SAMPLING USed $4.5 \mathrm{~g}$ for TSI mass & \\
\hline H2O (5 gram) & $2.97 \mathrm{pCl}$ per gram & TOTAL VOLUME PER SAMPLE & 0.20 Liter \\
\hline $\begin{array}{r}\text { ALPHA pet SAMPLE } \\
\text { NH3 (5 gram) }\end{array}$ & $0.11 \mathrm{pCi}$ per gram & $\begin{array}{l}\text { Tritium per Sample } \\
\text { IST (4.5 gram) }\end{array}$ & $0.33 \mathrm{pCi}$ por gram \\
\hline $\mathrm{H} 2 \mathrm{O}(5 \mathrm{gram})$ & 0.11 pCi per gram & ALPHA per Sample & \\
\hline BETA per SAMPLE & & IST ( 4.5 pram) & $0.01 \mathrm{pCl}$ per gram \\
\hline NH3 (5 gram) & $30.16 \mathrm{pCl}$ per gram & BETA per Samplo & \\
\hline $\mathrm{H} 2 \mathrm{O}(5 \mathrm{gram})$ & 30.16 pCi per gram & TST $(4.5 \mathrm{gram})$ & 3.35 pCiper grem \\
\hline GEA per SAMPLE (Cs 137) & & GEA per SAMPLE (Cs 137) & \\
\hline \multirow{3}{*}{$\begin{array}{l}\text { NH3 }(5 \text { gram) } \\
\text { H2O (5 gram) }\end{array}$} & $36.64 \mathrm{pCi}$ per gram & $\mathrm{TST}(4.5 \mathrm{gram})$ & $4.07 \mathrm{pCl}$ per gram \\
\hline & $36.64 \mathrm{pCi}$ per gram & SUMUA SAMPLING & \\
\hline & & $\begin{array}{l}\text { TOTAL VOLUME PER CANISTER } \\
\text { TritiU PER SAMPLE } \\
\text { ALPHA PER SAMPLE } \\
\text { BETA PER SAMPLE } \\
\text { GEA PER SAMPLE (Cs 137) }\end{array}$ & $\begin{array}{l}6 \text { Lifters (air at } 300 \mathrm{~K}, 1 \text { bet }=1.161 \mathrm{~g} 几 \text { ) } \\
6.39 \mathrm{pCl} \text { per gram } \\
0.23 \mathrm{pCl} \text { per gram } \\
64.94 \mathrm{pCl} \text { per gram } \\
78.90 \mathrm{pCl} \text { per gram }\end{array}$ \\
\hline
\end{tabular}

PARALLEL DOWNSTREAM FILTER

TOTAL VOLUME

ALPHA
BETA
GEA

Co-60
Cs- 134

Cs-134

Cs-137

Eu-152

Eu-154
Eu-155
$\mathrm{Ci} /$ liter

$\begin{array}{rr}0.27 & 0.27 \\ 34.70 & 34.70\end{array}$

\begin{tabular}{rr}
34.70 & 34.70 \\
$<$ & 12.64 \\
\hline & 12.64
\end{tabular}

$<9.919 \quad<9.919$

$45.40 \quad 45.40$

$<50.24<50.24$

$<31.29$

32.19 
HNF - SD-WM-RPT-262， Rev . 0

This page intentionally left blank.

A -7 
HNF-SD-WM-RPT-262，Rev. 0

APPENDIX B

AMBIENT CONDITIONS

B - 1 
HNF-SD-WM-RPT-262，Rev . 0

This page intentionally left blank. 
WEATHER DURING ISVS SAMPLING OF 241-U-104

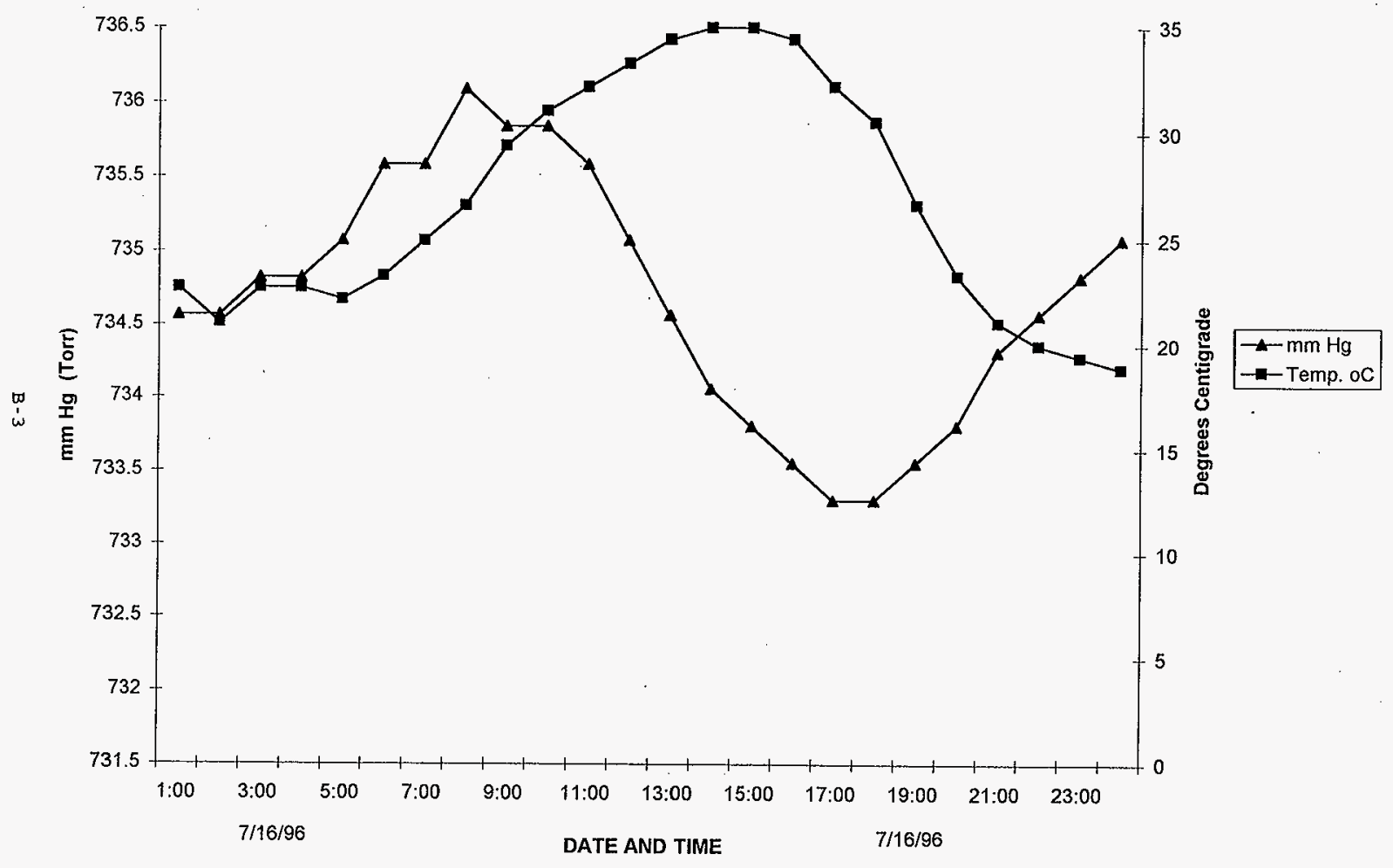


HNE-SD-WM-RPT-262， Rev , 0

This page intentionally left blank.

B- 4 
HNF - SD - WM-RPT-262，Rev. 0

APPENDIX C

CHAIN-OF-CUSTODY FORMS

C-1 
HNF - SD - WM- RPT - 262, Rev , 0

This page intentionally left blank.

C- 2 
HNF-SD-WM-RPT-262， Rev . 0

Battelle Pacific National Northwest Lab

Custody Form Initiator

Company Contact

R. D. Mahon - WHC

Project Designation/Sampling Locations 200 West Tank Farm

241-U-104 Tank Vapor Sample SAF S6072

(ISVS Cart)

Ice Chest No.

Bill of Lading/Airbill No.

$N / A$

Method of Shipment

Government Truck

Shipped to

PNNL

Possible Sample Hazards/Remarks Unknown at time of sampling
$\mathrm{S} 6072-\mathrm{A} 01.013$
$\mathrm{S} 6072-\mathrm{A} 02.029$
$\mathrm{S} 6072$ - $\mathrm{A} 04.050$
$\mathrm{S} 6072$ - A05 . 055
S6072 - A06. 099
Collect SUMMA \#3
Collect SUMMA \#4
Collect SUMMA \#5

Collect Ambient Air Sample SUMMA \#1

Collect Ambient Air Sample SUMMA \#2 (through tube bundle)

\begin{tabular}{|c|c|c|c|c|c|}
\hline ( I Field Transfer of Custody & & X] Chz & Possession & d Print Name & \\
\hline Relinouished By & Dete & Time & Received By & Date & Time \\
\hline JAEdwards $f$ - 4 celecrecelo & $07-12-96$ & 1030 & GSCAPRID is Con & $07-12-96$ & 1030 \\
\hline GSCAPRIO $\$ D C N=$ & $10-8+96$ & 0950 & 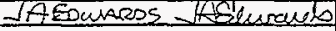 & $10-8-96$ & 0950 \\
\hline & & & & & \\
\hline & & & & & \\
\hline
\end{tabular}

Comments:

Final Sample Disposition

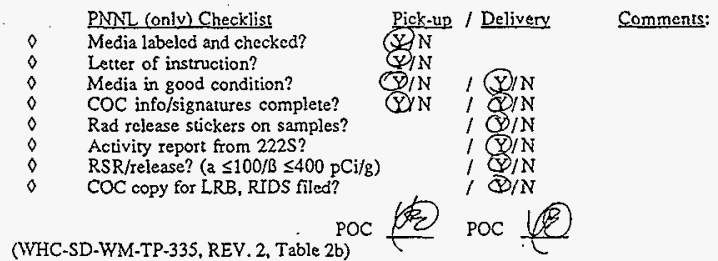

Telephone (509) 373-0141

Page 85-3009/FAX 376-2329

Telephone

(509) 373.2891

Page 85-3656/FAX 373-3793

Collection date $07 \cdot 16 \cdot 96$

Preparation date

$07-12-96$

Field Logbook No, WHC. N- $=-147.8$

Offsite Property No. N/A 


\section{\begin{tabular}{l|l}
\hline attelle Pacific & CHAIN OF CUSTODY \\
Northwest Laboratory & \\
\hline
\end{tabular}}

Custody Form Initiatox

J. A. Edwards - PNL

Company Contace

F. D. Mahon - WHC

Project Designation/Sampling Locations 200 West Tank Farm 241-U-104 Tank Vapor Sample SAF S6072

Ice Chest No. (ISVS Cart)

Ertco Hillo themometer No. PNL-T-004

Bill of Iading/Airbill No.

$N / A$

Govemment Truck

Method of Shipment

WHC

Shipped to
WHC 100254
Telephone (509) 373-0141

Page .85-3009/P8-08/FAX 376-0418

Telephone (509) 373.7437

Page 85-9656/S3-27/FAX 373-7076

Collection date $07.16-96 \quad$ '

Preparation date. $07-08 \cdot 96$

Field Logbook rio. WHC.N. -647.8

Offsite Property No. N/A

Possible Sample Hazaros/Remarks Unknown at time of sampling

Sample Identification

S6072 - A11 . 1098 . S6072 - A12 . 1099 .

S6072 - A13 . 1100 .

S6072 - A14 - 1101 .

S6072 - A17. 1102 .

S6072 - A18 . 1103 .

$\$ 6072$. A19 . 1104 . $\mathrm{S} 6072$ - A20. 1105 .
PNL Triple Sorbent Trap (TST) Sample \# 1

PNL TST Sample \# 2

PNL TST Sample \# 3

PNL TST Sample \# 4

Open, close \& store TST Field Blank \$1

Open, close \& store TST Field Blank 푸 2

Store TST Trip Blank

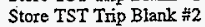

\begin{tabular}{|c|c|c|c|c|c|}
\hline Field Transfer of Custody & & [X] Chai & f Possession & nd Print Name & \\
\hline Relinguisbed $\mathrm{By}$ & Date & Time & Received By & Date & Time \\
\hline 12 Ques & $07-12-96$ & $8: 25$ & IA Edwards CAAPQLcoen & $07-12-96$ & 0825 \\
\hline 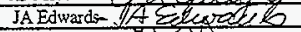 & 07.1296 & 1025 & $6 s$ ctero $\mathrm{ND}$ Cal $\rightarrow$ & $07-1296$ & 1025 \\
\hline cs capero $10<1]>$ & $10-8.96$ & 0950 & LAEOWAros JAEdureves & $10-8-96$ & 0950 \\
\hline & & & & & \\
\hline & & & & & \\
\hline & & & & & \\
\hline & & & & & \\
\hline
\end{tabular}

Comments:

BNL (only) Checklist

Media labeled and checked?

Letter of instruction?

Media in good condition?

$\mathrm{COC}$ info/signatures complete?

Sorbents shipped on ice? $\left(<5^{\circ} \mathrm{C}\right)$

$\mathrm{Hi} / \mathrm{LO}$ thermometer - Keep upright!

$\mathrm{Hi} / \mathrm{L}$ o thermometer

Rad release stickers on samples?

Activity report from 2225 ?

COC copy for LRB, RIDS filed?

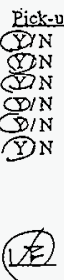

Final Sample Disposition 


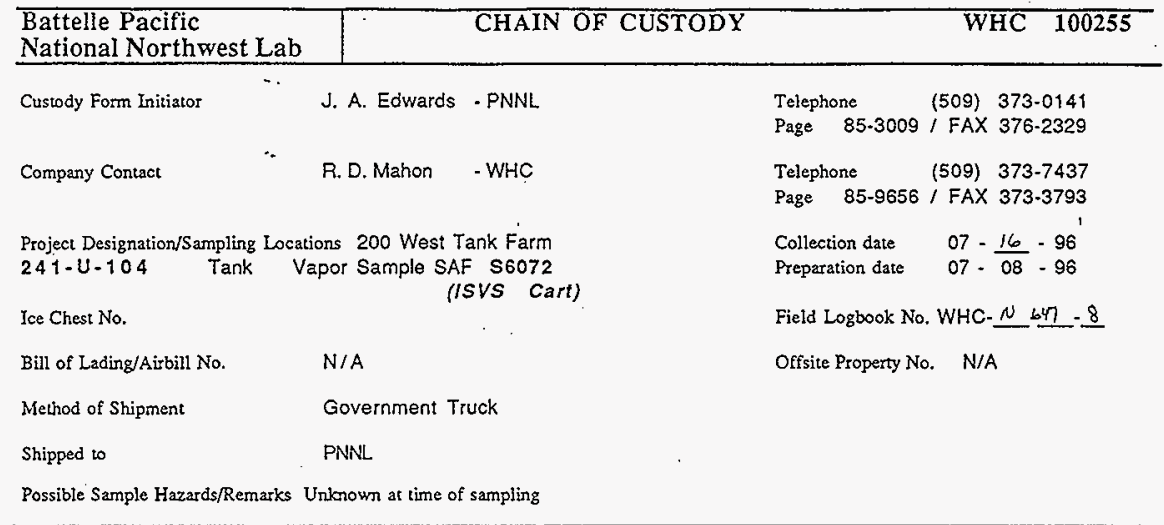

Sample Identification

$\begin{array}{ll}-\mathrm{S} 6072-\mathrm{A07} .34 \mathrm{R} & \text { Collect } \mathrm{NH}_{3} \mathrm{NO} / \mathrm{NO}_{\mathrm{X}} / \mathrm{H}_{2} \mathrm{O} \text { Sorbent Trap } \\ \mathrm{S} 6072-\mathrm{A} 08.35 \mathrm{R} & \text { Collect } \mathrm{NH}_{3} / \mathrm{NO}_{\mathrm{X}} / \mathrm{H}_{2} \mathrm{O} \text { Sorbent Trap } \\ \mathrm{S} 607.2-\mathrm{A} 09.36 \mathrm{R} & \text { Collect } \mathrm{NH}_{3} / \mathrm{NO}_{x} / \mathrm{H}_{2} \mathrm{O} \text { Sorbent Trap } \\ \mathrm{S} 6072-\mathrm{A} 10.37 \mathrm{R} & \text { Collect } \mathrm{NH}_{3} / \mathrm{NO}_{X} / \mathrm{H}_{2} \mathrm{O} \text { Sorbent Trap }\end{array}$

S6072 - A15 . 38R Open, close and store $\mathrm{NH}_{3} / \mathrm{NO}_{\mathrm{X}} / \mathrm{H}_{2} \mathrm{O}$ field blank \#1

S6072 - A16.39R Open, close and store $\mathrm{NH}_{3} / \mathrm{NO}_{\mathrm{X}} / \mathrm{H}_{2} \mathrm{O}$ field blank \#2

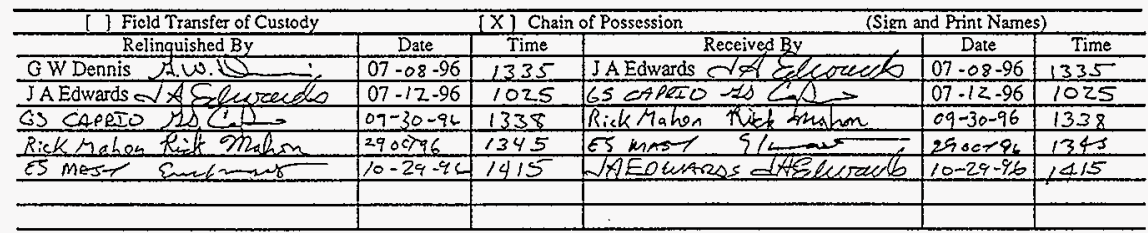

Comments:

Final Sample Disposition

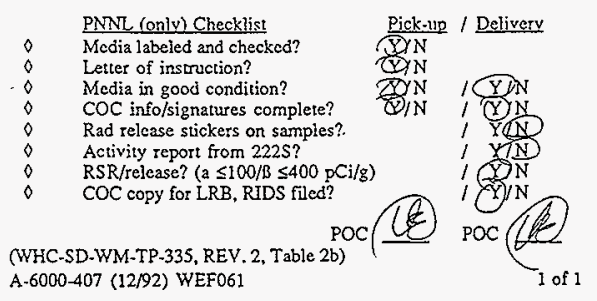

Comments:

$56072-407.34 P$ was moved to $\operatorname{COC} 100519$ to allow WSCF to perform a desturtive analysis of the $\mathrm{NH}_{3}$ and silica gel tube. The two Nox tubes were meved 6 COC 100520 for return te PNNL. Rom 3 ot 796

(Revised 05/30/96 PNNL) 


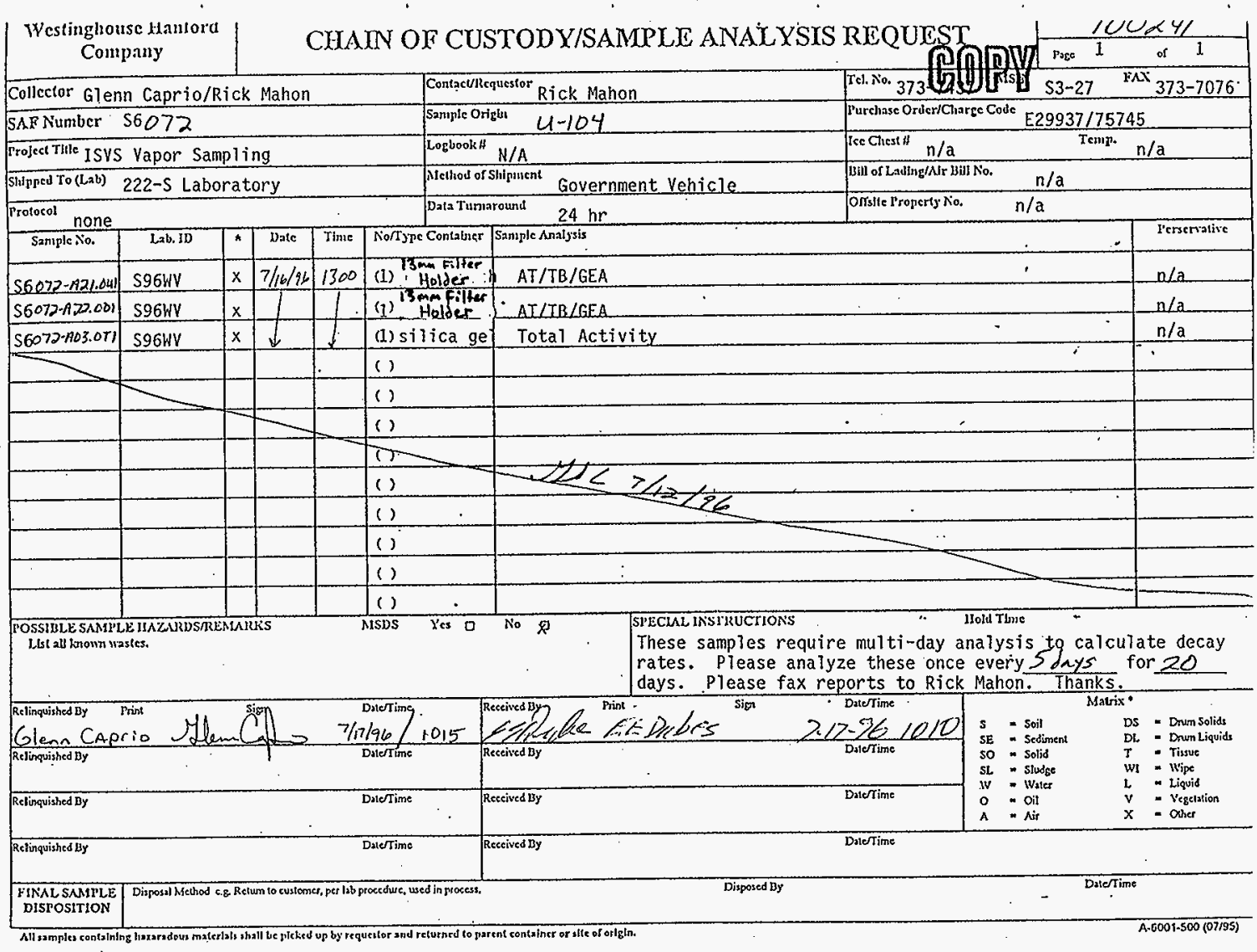




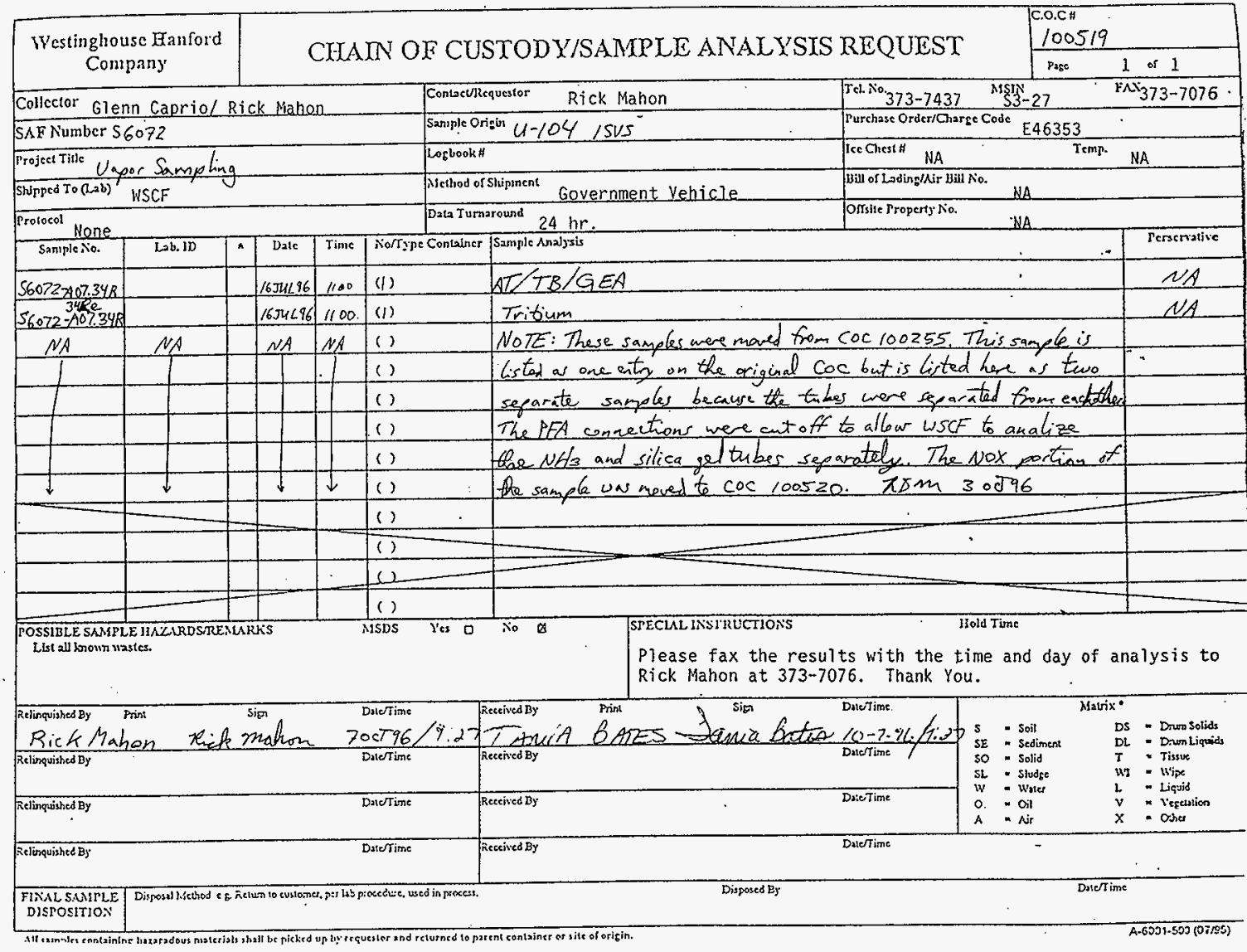




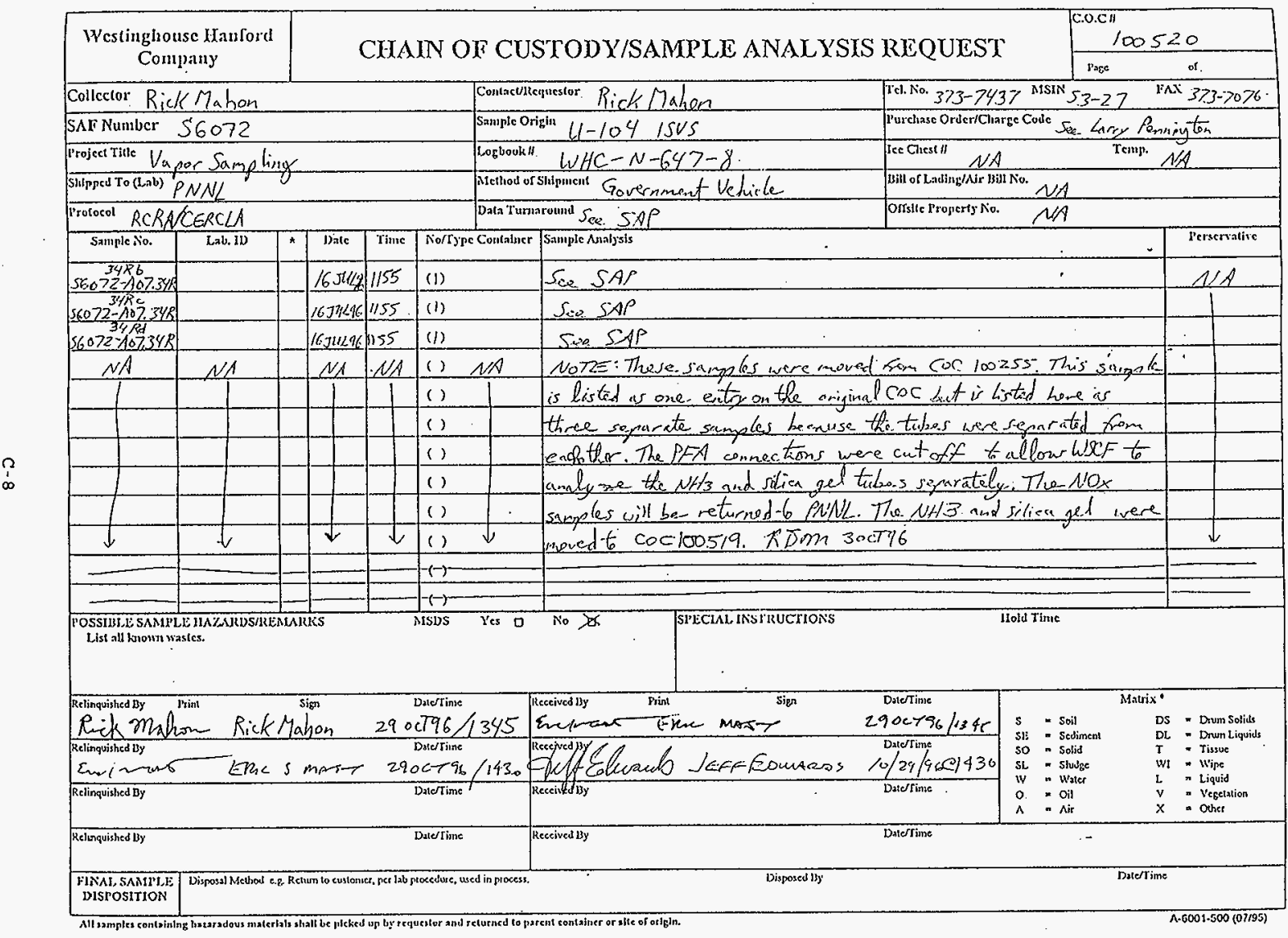




\section{DISTRIBUTION SHEET}

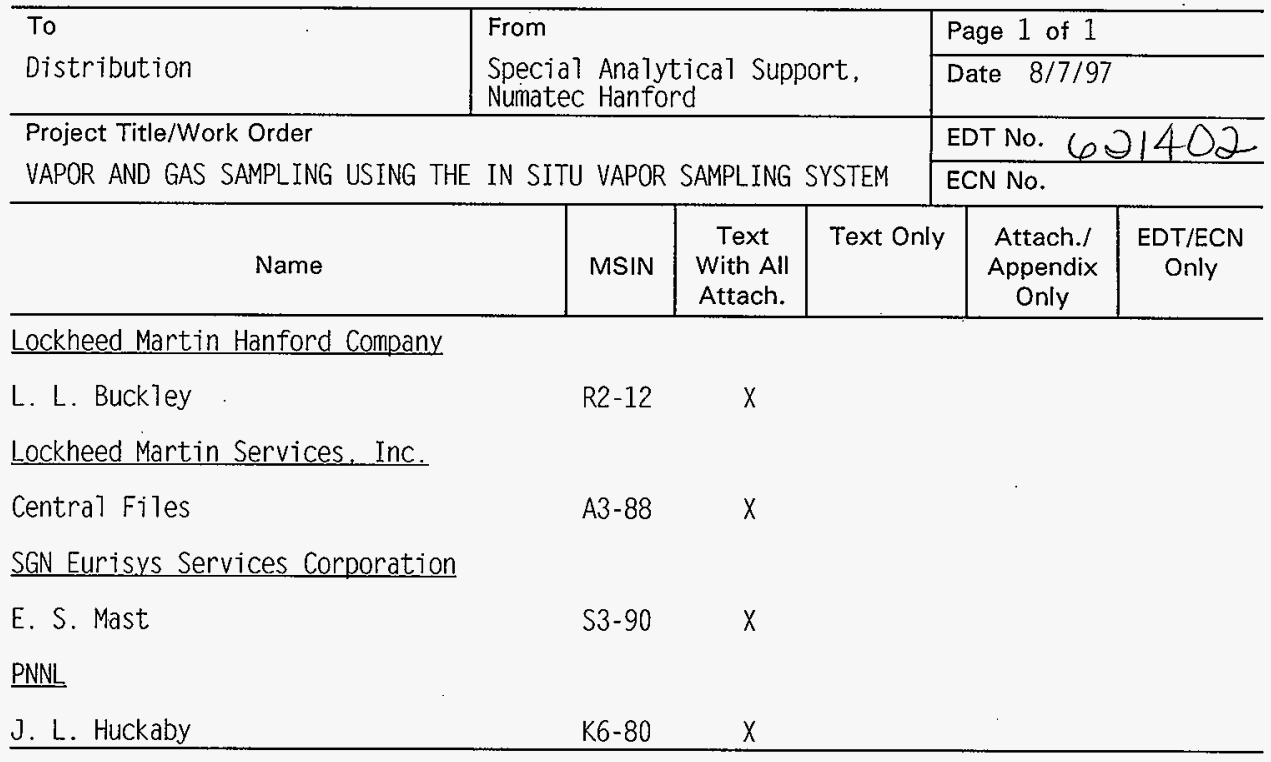

